\title{
BETWEEN ENCLAVEMENT AND EMBRACEMENT: PERSPECTIVES ON THE ROLE OF RELIGION IN RECONCILIATION IN SOUTH AFRICA ${ }^{1}$
}

Johan Cilliers

Practical Theology

Stellenbosch University

\begin{abstract}
This article takes a brief look at two indicators of the state of reconciliation in South Africa, provided by the National Planning Commission of the Government, as well as the South African Reconciliation Barometer survey, initiated by the Institute for Justice and Reconciliation. This is followed by a description of some theological efforts that have been made to outline spaces for cultural inter-facing within the South African context, and the article is concluded with a reference to the tension between the syndrome of 'enclavement', and the theological metaphor of 'embracement', as proposed by Miroslav Volf.
\end{abstract}

Key Words: Reconciliation, Religion, Enclave, Embracement

\section{Reconciliation in South Africa?}

To what extent, if any, has reconciliation taken place in post-apartheid South Africa? Two official sources paint a somewhat bleak picture. The National Planning Commission of the Government (NPC) was established in 2010 with a mandate to ensure greater interdepartmental planning within government, developing a long-term plan for the country, and drafting a vision for South Africa. In June 2011, the NPC released a diagnostic report on the current challenges facing the country, which was followed by a Draft National Plan for public consultation and input in November 2011. ${ }^{2}$

According to The National Planning Commission, the foremost challenges currently facing the country are, in broad terms: "high unemployment; low educational quality, for black people in particular; inadequate infrastructure; significant spatial development challenges; a resource-intensive and unsustainable growth path; an ailing public health system unable to cope with the national disease burden; uneven public sector performance; and corruption" (NPC, 2011a).

A specific diagnostic was also conducted on progress in reconciliation and nationbuilding, and the National Planning Commission reported that despite progress in the country since the transition to democracy in 1994, South Africa still "remains deeply divided and characterised by high levels of inequity and inequality." These "disturbing

This article was first delivered as a paper at the International Summer School held in collaboration between Humboldt University (Berlin, Germany), Stellenbosch University (South Africa), and the School of Religion, Philosophy, and Classics, University of KwaZulu-Natal, Pietermaritzburg campus (South Africa), on 28 March to 2 April 2012, on the theme: The Social impact of Religious Communities.

2 As quoted from The South African Reconciliation Barometer Survey: 2011 Report. (Ed.) Kate Lefko-Everett, Ayanda Nyoka and Lucia Tiscornia. Published by the Institute for Justice and Reconciliation, 7. 
divisions' were ascribed to economic underperformance and deeply entrenched patterns of historic privilege and deprivation (NPC, 2011f:412).

The findings of a second institution, the South African Reconciliation Barometer $(\mathrm{SARB})^{3}$ dovetail with those of the NPC. The South African Reconciliation Barometer survey is a nationally representative public opinion poll conducted annually by the Institute for Justice and Reconciliation (IJR), which focuses on progress in reconciliation in South Africa. The SARB measures progress in reconciliation through six complex hypotheses and indicators, which are: political culture, human security, cross-cutting political relationships, dialogue, race relations and historical confrontation. In other words the barometer aims to deduce how the abovementioned aspects influence reconciliation in South Africa and is a joint project of the IJR and the Khayabus opinion poll of Ipsos-Markinor which collects data through interviews with a nationally representative sample of 3487 South Africans. There is a presumption that $95 \%$ of the data is accurate and a possible deviation of $1,7 \%$ is calculated.

What follows represents a summary of some findings of the NPC, as well as the SARB survey, particularly in regard to reconciliation:

- The year 2011 has provided ample evidence of the growing gap between South Africa's few 'haves' and millions of 'have-nots'. This gap between rich and poor continues to be identified as the biggest social division in the country, ahead of political party membership, race, infectious disease, religion or language.

- The year 2011 has also brought clear indications of just how quickly public opinion can become extremely polarised, often along historic dividing lines and with little neutral space for dialogue in between.

- That South Africa remains a deeply divided society has been a discouragingly consistent finding of the SARB survey, conducted by IJR since 2003.

- Consecutive rounds of the SARB have found that South Africans continue to associate strongly with identity groups based on language, ethnicity and race.

- In June 2011, the NPC's Diagnostic Overview found that "South Africa remains a divided society and the major dividing line is still race" (NPC, 2011a:26). The subsequent National Plan suggests that a common goal for the country should be to reach a point at which "South Africans become more conscious of the things they have in common than their differences" (NPC, 2011f:414).

- The challenges that face the country at present are difficult, but they are not insurmountable - what is needed is to effectively open up a public space for constructive dialogue about these challenges, and how best to move forward as a country.

\section{The Search for Spaces for Cultural Inter-Facing ${ }^{4}$}

In the light of the SABR Survey, as well as the diagnostic report of the NPC, a basic question facing South African society after apartheid still seems to be: can we have both national unity and celebration of our diversity? ${ }^{5}$ And, of specific importance for this

The South African Reconciliation Barometer Survey: 2011 Report. (Ed.) Kate Lefko-Everett, Ayanda Nyoka and Lucia Tiscornia. Published by the Institute for Justice and Reconciliation.

4 I have written about this challenge in Cilliers, JH 2007. Religious and cultural transformations and the challenges for the churches - A South African Perspective. Praktiese Teologie in Suid-Afrika Desember 22 (2): 1-19. This article intends to take this argument further and flesh out some concrete implications.

5 Linked to this could be the question of the relationship between the effects of globalisation and the call for glocalisation. The latter phrase was coined by Robertson (1992) as an indication of the importance of local 
article, what role can religion and religious communities play in answering this question? According to Villa-Vicencio (1994:115-126), there are different options for the coexistence of unity and diversity, ranging from unfavourable (in some cases, downright dangerous) to potentially viable.

One option would be that of cultural assimilation, in which cultures and cultural differences are assimilated into one another, up to the point where a fully homogenised end product is created, under so-called 'social consensus'. The problem with this, however, is the role of power, with the accompanying question: who determines the process (and even outcome) of the so-called consensus? Cultures that are not in consensus with the rest may be marginalised, or will remain so, being alienated and excluded to the detriment of the richness of our diversity. This option seems to stress unity to the detriment of diversity.

A second possibility would be one of multicultural pluralism, in which people from different cultures, ethnic and racial origins, as well as genders and religions have the right and freedom to express their identities within the character and the decision-making processes of the public realm (Villa-Vicencio 1994:117-118). Within this model ethnicity and culture seem to be the driving forces in determining individual and social identity, and it would be a valid question to ask whether these emphases, given our history, will heal our society or rather prompt a regression into apartheid once again. The problem here again is the question of power, the dominant forces and role players, as opposed to the marginalised. Whilst cultural assimilation stresses unity to the detriment of diversity, multicultural pluralism tends to over-emphasise diversity against unity.

A third option could be cultural engineering, in which a certain amount of intervention in or moulding of, cultures could take place. Obviously, although South Africa is presently going through a period of reconstruction, which entails certain measures to redress the imbalances of the past, for South Africans emerging from apartheid the very thought of cultural manipulation is hard to swallow. The concept of intervention begs the question of power once again: who does the engineering, and with what agenda? In my opinion, this option could in fact destroy not only the communal discovery of a new unity, but also the richness of our diversity in our quest for a new identity.

What in fact is needed is an approach that ensures cultural openness (Villa-Vicencio 1994:120). This involves a co-mingling of cultures, which does not mean an assimilation, consummation or fusion of one within the other. Rather it operates with the presumption of equal worth and openness to the possibility of discovering together something that encompasses our particular cultures, but is also bigger than the sum total of that which we bring to the national table.

In my opinion this notion of cultural openness needs to be developed further, specifically with the potential role of religion in mind. ${ }^{6}$ Cultural openness could also be described in terms of interculturality, ${ }^{7}$ as opposed to inculturality. ${ }^{8}$ The concept of

issues and the impact of culture on local communities. Glocalisation guards against the tendency of globalisation to homogenize.

6 I have debated this notion extensively in Cilliers, JH 2009. Creating space within the dynamics of interculturality: the impact of religious and cultural transformations in post-apartheid South Africa. Wilhelm Gräb, Lars Charbonnier (Eds.) Secularization Theories, Religious Identity and Practical Theology. Proceedings of the IAPT Conference Berlin 2007. Reihe: International Practical Theology Bd. 7. Berlin: Transaction Publishers. 260-270.

7 Interculturality is a set of processes through which relations between different cultures are constructed on a basis of equality and mutual respect. This concept emerged towards the end of the twentieth century as a correction or expansion of the existing paradigm of inculturality. Whilst inculturality emphasizes the fact that 
interculturality could in turn be refined from the perspective of interpathy. ${ }^{9}$ The latter denotes more than just sympathy. It is an inclusive compassion that is not only directed towards individuals, but also cultures and values. It operates from an unbiased, unconditional love, taking the ethics of love into systemic paradigms. Interpathy goes far beyond a condescending attitude ${ }^{10}$ of a 'superior' culture sympathising with an inferior one, or giving handouts on the grounds of misguided compassion. It does not romanticise either viewing, for instance, African culture through a rosy tourist lens of tribal drums, wooden artefacts or colourful traditional dresses. Interpathy, as mode of interculturality, operates from the basis of mutual respect, openness to the other, reciprocal understanding, compassion and enrichment. It adheres to a porous hermeneutics, in which the supposed boundaries of epistemologies are revisited frequently and crisscrossed in a spirit of genuine teachability.

interpenetration takes place between cultures, interculturality emphasises exchange. The theological rationale for inculturality can be found in incarnational theology, stressing the fact that in this process the gospel can and should be enfleshed and embodied within the paradigm of a specific local culture (Cf. Louw 2006:8-9). From a vast body of literature on this concept, the following may serve only as indication: Bennett, Milton (1998). Overcoming the Golden Rule: Sympathy and Empathy, in: Basic Concepts of Intercultural Communication. Selected Readings. Yarmouth \& London: Intercultural Press, pp.191-214; Bhabha, Homi K. (1994). The Location of Culture. London: Routledge; Brislin, Richard W. \& Yoshida, Tomoko (Eds.) (1994). Improving Intercultural Interactions. Modules for Cross-Cultural Training Programs. Thousand Oakes, London, New Delhi: Sage; Brocker, Manfrend \& Nau, Heino H (Hrsg.) (1997). Ethnozentrismus. Möglichkeiten und Grenzen des interkulturellen Dialog. Darmstadt: Wissenschaftliche Buchgemeinschaft; Cesana, Andreas (Hg) (1999). Interkulturalität - Grundprobleme der Kulturbegegnung. Mainzer Universitätsgespräche. Sommersemester 1998. Mainz, Trier: Gutenberg Universitätsverlag; Demorgon, Jacques (1999). Interkulturelle Erkundungen. Möglichkeiten und Grenzen einerinternationalen Pädagogik. Europäische Bibliothek interkultureller Studien Bd. 4. Frankfurt am Main: Campus.

8 The problem of inculturality could once again be that of power - it can easily happen that inculturation, though meant well, ends up by being 'Christianization', in which the dominant culture of those doing the Christianization is imposed on the receiving culture. In the intercultural approach the separation between Christ and culture is no longer accepted, nor the domination of one (Christian) culture over the other, but rather the interconnectedness between Christ and culture. It focuses on the meaning of Christian spirituality within culture as well as the mutual exchange of paradigms between the two, a sharing with the intention to empower within a relationship of reciprocity. One is reminded of the classical distinctions concerning the relationship between Christian faith and culture (Christ and Culture) proposed by HR Niebuhr in 1951. He describes the rejection and anti-model: Christ against culture (58-92; the accommodation model: the Christ of culture (93-122); the synthesis model; Christ above culture, i.e. to maintain both the distinctions between Christ (his Lordship) and culture as well as the relatedness to culture, 'both-and' (127-128); the dualistic model: Christ and culture in paradox (154-191); and the operational model: Christ the transformer of culture (192-228). Niebuhr himself believes that, although Christ is above culture (different), He operates through it to transform (convert) it. He still works with the so-called object-subject split in a polar model, i.e. the presupposition that according to the substantial difference between the two, the relationship has to be reestablished (cf. Louw 2006:8).

9 First used by David W Augsburger in his Pastoral Counseling Across Cultures, Philadelphia: Westminster, 1986. According to him interpathy is "an intentional cognitive envisioning and affective experiencing of another's thoughts and feelings, even though the thoughts rise from another process of knowing, the values grow from another frame of moral reasoning, and the feelings spring from another basis of assumptions" (1986:56).

10 Often our (body) language reveals our self-absorbing interests. Language, of course, remains a significant element of intercultural communication. "Language is the medium through which a culture expresses its world view... Like culture in general, language is learned and it serves to convey thoughts; in addition it transmits values, beliefs, perceptions, norms, and so on" (Jandt 2004:224). "Vom ersten Moment an hat sich Sprache als wesentliches Element in interkulturellen Begegnung herausgestellt. Begegnung zwischen Menschen unterschiedlicher Kulturen ist Übersetzungsarbeit, die allerdings nur bedingt gelingt" (Federschmidt et al. 2002:19). 
In this regard religion can make a meaningful contribution - not, as unfortunately happens time and again, functioning as an agent that legitimises the status quo of cultural boundaries or separateness. It's dimension of spirituality should rather help to safeguard society from changing that which is only temporal into something permanent or eternal, giving that which is transient a rigid, stable value. Religion should serve the movement from stringency to contingency, from status quo to status flux. Religion can help create a space for graceful neighbouring. ${ }^{11}$

The notion of creative and respectful space ${ }^{12}$ might be explored further. The IJR already referred to above - which in the past has facilitated several interactions in communities across the country, aimed at creating and fostering dialogue between former enemies and ordinary citizens who endeavour to build a common future after generations of violent conflict, has developed an approach that aims at so-called 'safe spaces' (cf. Du Toit 2003:212-217). These spaces originate in relationships where honesty is a sine qua non, but held in tension with respect. In other words: differences are put on the table and not hidden or masked, but these differences may never lead to disrespect of the other. On the other hand, acknowledgment of past and present transgressions is held in tension with responsibility - a deep confession coupled with the sincere desire to act and to transform that which was and still is wrong in our society. In this way, through mutual adherence to these four basic values, a framework for dialogue in a 'safe space' can be created: honesty, but with respect; acknowledgment, but with responsibility.

The concept 'safe space' does not indicate neutrality or inactivity, or a new type of securocracy. ${ }^{13}$ On the contrary, it intends a spiritual space of intimacy, where reciprocal enrichment can take place. Perhaps we can coin a helpful phrase here: what is needed in South Africa is an intercultural and interpathetic space for redefining our identity. Religion, being part of culture, can operate as a definitive and formative space-creator and space-setter within culture.

Within this space, a new South African identity may be formed. Within this space we have reached a deep level of the South African story: the search for identity. I am of the opinion that what transpires at this core in the years to come will influence all the layers of our society; that our mutual understanding of our identity will in fact be the most profound

11 Diana Nishita Cheifetz has written a beautiful essay on graceful neighbouring, which she sub-titles: Dancing with our diversity. She uses the metaphor of dance to illustrate some rules or guidelines for 'graceful neighbouring' - one could say, interculturality. The first is simply to be aware of others on the dance floor of society (2006:16). Not to be so self-focused and engrossed with your 'own' movements, but rather gracefully becoming part of the whole. A second rule would be to acknowledge, with respect, the others around you very much like the curtsy with which medieval dancers opened up the dance. To acknowledge one another is to accept and respect the 'otherness' of the other. A third rule could be added to this: to respect the space, and from time to time even to create the space, between dancers. There should be closeness without familiarity, but also space without alienation. Graceful neighbouring can mean honouring the space in between, so that we can move together respectfully even with our differences (2006:22). Of course, dancing is also something that must be learnt. Before mastering it, many toes might be stepped on and many egos end up stretched out on the floor!

12 The notion of space is of course not a new one. The Greeks already referred to the importance of space in our quest for being human. The Greek word Chora means space or place and could also be interpreted as the attitude through which humans fill space with values, perceptions and associations, resulting in a created relational environment, a systemic and hermeneutical arena for living with meaning and dignity. Chora represents a nourishing and maternal receptacle, a womb that defines the quality of the places (topoi) where we encounter one another. Indeed, in this space we cannot exist without one another; it is where we meet in our diversity and unity, but also as perpetrators and victims.

13 John de Gruchy, referring to the art of reconciliation, speaks of the creating of space for interfacing in a postapartheid South Africa (2002:148-149). 
factor in shaping our communal future. It is exactly here, in my opinion, that the church and religion face their deepest challenge: either to be a stagnant or even destructive role player, or a heuristic agent that acts as midwife for our country in the fulfilment of her new birth.

\section{Moving from Enclavement to Embracement}

But perhaps the mere creation of spaces for inter-facing does not go far enough. It would seem that the syndrome of enclavement still permeates at least certain sectors of the South African cultural landscape. Taking 'Afrikaner Identity' as a case in point, the following diagnosis can indeed be made:

An enclave - like for instance formed around 'Afrikaner Identity' before and during apartheid - differentiates itself from other groups in order to create internal cohesion. An enclave is directed against the 'other', which could, again in the instance of historical Afrikaner identity, be seen as 'other' empires (like the British - during the Boer wars), 'other' races (as expressed during apartheid), 'other' languages (as exemplified during the so-called 'language movement': or 'Taalbeweging'), etc. Enclaves often operate with syndromes of anxiety (the 'black danger', or the 'red, i.e. Communist danger', etc.) and (often extreme) efforts to maintain the 'purity' of the enclave. In typical enclave mentality, you are either 'in' or 'out'. No compromise, no grey areas - things are black and white (Cilliers and Nell 2011:8; cf. also Aaboe 2007:65).

Searching for a theological metaphor that opposes this syndrome of enclavement, we are reminded of the classic work of Miroslav Volf, entitled Exclusion \& Embrace: A Theological Exploration of Identity, Otherness, and Reconciliation. Enclavement could as well be called exclusion; exclusion forms the core myth of the enclave.

A Croatian by birth, Volf takes as a starting point for his analysis the civil war and 'ethnic cleansing' in the former Yugoslavia, but he readily finds other examples of cultural, ethnic, and racial conflict to illustrate his points. Volf proposes the idea of embrace as a theological response to the problem of exclusion. He argues that 'exclusion' of people who are alien or different is among the most intractable problems in the world today. He writes, "It may not be too much to claim that the future of our world will depend on how we deal with identity and difference. The issue is urgent. The ghettos and battlefields throughout the world - in the living rooms, in inner cities, or on the mountain ranges - testify indisputably to its importance" (1996:57f.). Yes, perhaps the future of South Africa also depends on how we deal with 'otherness'.

Volf speaks about the 'drama' of embrace in four acts (1996:140-147), keeping in mind that the notion of 'embracing' might be viewed differently in different cultures. For him, it however forms a basic metaphor for moving out of the exclusion of the enclave. Volf however also offers a distinct theological underpinning for this concept: the Christian scriptures attest that God does not abandon the godless to their evil, but gives of God self to bring them into communion. We are called to do likewise - whoever our 'enemies' and whoever we may be. The fourfold structure of embracement proposed by Volf could be summarised briefly as follows:

The first act of embracing entails opening up your arms. This indicates a code of desire for the other, and a "sign that I have created space in myself for the other to come in and that I have made a movement out of myself so as to enter the space created by the other." (1996:141) As first act it suggests a fissure in the self and a gesture of invitation.

Perhaps the South African Truth and Reconciliation Commission (TRC) represented such a first opening up of the arms in our history of, and struggle for, reconciliation. The TRC was 
hailed - and criticised - as unique inter alia because of its "overriding focus on reconciliation as a primary goal of its work", and not just judicial outcomes (Hayner 2000:36), as well as because of the strong religious, even explicitly Christian undertones, that inevitably colored concepts such as truth, reconciliation, remembrance, justice, restitution, etc. (Mouton and Smit 2008:50, 51; cf also Cilliers 2011:78-89). But the work of the TRC was indeed not an end in itself; rather it was a point of departure, an initiation into a new South Africa that would hopefully operate with a new ethos and indeed spirit of reconciliation between its citizens (cf. Du Toit 2006:199; Villa-Vicencio 2006:2-8; Maluleke 2006:103, etc.). After its final sessions, many South Africans still felt that reconciliation did not really take place, and that reconciliation indeed cannot, and should not, be forced or implemented to act as a premature pacifier.

Significantly, Volf also speaks of the second act of embracement as one of waiting. "The waiting self can move the other to make the movement toward the self, but its power to do so is the power of signalled desire, of created space, and opened boundary of the self, not the power that breaks the boundaries of the other and forces the fulfilment of desire" (1996:142-143). Embracing does not mean grasping the other through force of power.

This act of waiting does not however mean that we should be passive in our quest for reconciliatory embracement. It is rather a time for listening to one another, of learning to trust one another, or in the words of Desmond Tutu himself:

The TRC was an important turning point for South Africans - but it was only a starting point. We need to keep working at reconciliation... We are in many ways still strangers to one another. We have got to get to know and to trust one another. We need to tell one another about our hurts and our fears. We need to heal one another's wounds. We need to listen to one another's stories. This can open a space within which to address the economic and other woes that our people face. If reconciliation does not lead to people contributing in some way to transformation and the improvement of the lives of all South Africans it will, with some justification, be dismissed as a factitious thing to be ignored (quoted in Villa-Vicencio and Du Toit 2006:i).

But, according to Volf, there must also be an act three: closing the arms. "This is the goal of embrace, the embrace proper, which is unthinkable without reciprocity..." (1996:143). This reciprocity does not indicate a hard touch, but rather the soft touch of respect. Embracing should not be perverted into a smothering or crushing 'bear-hug'. In this embrace the identity of the self is preserved and transformed, and the alterity of the other is affirmed and respected.

This 'embrace proper' signifies the stage where concrete issues concerning restorative justice needs to be fleshed out. This calls for dialogue, reciprocity - fostered by what theologians have called a new theological paradigm - a theology of reconstruction (VillaVicencio 1998:2 f.), or a theology of restitution (Maluleke 2008:684), going beyond a mere welfarist act of 'hand-outs' (Swart 2008:123,126). The fact that glaring economic inequalities lie at the root of many of South Africa's societal problems, and the view that the church should urgently take part in this debate, have been acknowledged many times before (cf. Smit 1984:71). In essence, what is needed is a theological paradigm that does not shrink from this debate, but rather helps to set the agenda and provide relevant content. According to Finca (2007:4), "Restitution is not a political issue. It is moral and ethical. It lies at the centre of moral theology."

Following Volf's metaphor, this phase of restorative embracement must however lead to act four: the opening of the arms again. "If the embrace is not to cancel itself, the arms must open again" (1996:144). The call to 'embrace the other' is never a call to remake the 
other into one's own image. In effect, Volf's theological understanding of embrace opens itself to religious pluralism by upholding the importance of different religious and cultural traditions for the formation of personal and group identity. This formation of identities may however never again deteriorate into new forms of 'apartheid'.

In summing up the implications of a theology of embrace for religious and cultural traditions, Volf in fact refers to the fluidity of identities, the nonsymmetricity of relationships, the underdetermination of the outcome, and the risk of this embrace (145-147). In short, "Embrace is grace, and grace is gamble, always" (1996:147).

Many South Africans still seek shelter within the so-called 'safe havens' of their enclaves - of that the findings of the South African Reconciliation Barometer and the diagnosis of the National Planning Commission provide ample evidence. However, there have been some indications of individuals and groups moving out and seeking spaces for inter-facing. The role of various religious communities might prove to be of decisive value in this process, but it must also be taken further: fostering gestures and acts of true embracement. For this, all the relevant values of the religious communities will be called to action: the crossing of borders towards the 'other', the respect of human dignity, the urgency of transparency and honesty, the need for dialogue and reciprocal teachability, the inclusion of the marginalised, etc.

Indeed: embrace is grace, and grace is gamble, always - but we might yet win.

\section{BIBLIOGRAPHY}

Aaboe, Julie 2007. The Other and the Construction of Cultural and Christian identity: The case of the Dutch Reformed Church in Transition. Unpublished PhD, University of Cape Town.

Augsburger, DW 1986. Pastoral Counseling Across Cultures. Philadelphia: Westminster.

Bennett, M 1998. Overcoming the Golden Rule: Sympathy and Empathy. (ed.), Basic Concepts of Intercultural Communication. Selected Readings. Yarmouth \& London: Intercultural Press. 191-214.

Bhabha, HK 1994. The Location of Culture. London: Routledge.

Brislin, RW \& Yoshida, T (eds.) 1994. Improving Intercultural Interactions. Modules for Cross-Cultural Training Programs. Thousand Oakes, London, New Delhi: Sage.

Brocker, M \& Nau, HH (Hrsg.) 1997. Ethnozentrismus. Möglichkeiten und Grenzen des interkulturellen Dialog. Darmstadt: Wissenschaftliche Buchgemeinschaft.

Cesana, A (Hrsg) 1999. Interkulturalität-Grundprobleme der Kulturbegegnung. Mainzer Universitätsgespräche. Sommersemester 1998. Mainz, Trier: Gutenberg Universitätsverlag.

Cheifetz, DN 2006. Graceful Neighboring: Dancing with our Diversity. In Weavings xxi:4 July/August 2006:15-23.

Cilliers, JH 2007. Religious and cultural transformations and the challenges for the churches - A South African Perspective. Praktiese Teologie in Suid-Afrika Desember 22 (2):1-19.

Cilliers, JH 2009. Creating space within the dynamics of interculturality: the impact of religious and cultural transformations in post-apartheid South Africa. Wilhelm Gräb, Lars Charbonnier (eds.) Secularization Theories, Religious Identity and Practical 
Theology. Proceedings of the IAPT Conference Berlin 2007. Reihe: International Practical Theology Bd. 7. Berlin: Transaction Publishers. 260-270.

Cilliers, JH 2011. Between Remembrance and Restitution: a practical theological investigation into the impact of the Truth and Reconciliation Commission (TRC) within the South African context of religion, diversity, and conflict. The International Academy for Practical Theology. 78-89.

Cilliers, JH; Nell, IA 2011. Within the enclave: Profiling South African social and religious developments Paper delivered at international and interdisciplinary conference, Berlin, 25-28.11.2010: The impact of global religious transformations on social cohesion and social development in different cultural contexts.

De Gruchy, JW 2002. Reconciliation. Restoring Justice. David Philip: Cape Town.

Demorgon, J 1999. Interkulturelle Erkundungen. Möglichkeiten und Grenzen einer internationalen Pädagogik. Europäische Bibliothek Interkultureller Studien Bd. 4. Frankfurt am Main: Campus.

Du Toit, F (ed.) 2003. Learning to live together. Practices of social reconciliation. Cape Town: Institute for Justice and Reconciliation.

Du Toit, Fanie. 2006. Beyond the TRC. In Truth and Reconciliation in South Africa: 10 Years On, (ed.) Villa-Vicencio, C; Du Toit, F, 199-204. Claremont: New Africa Books (Pty) Ltd.

Federschmidt, K; Hauschildt, E; Schneider-Harpprecht, C; Temme, K und Weiss, H (Hrsg) 2002. Handbuch Interkulturelle Seelsorge. Neukirchen: Vluyn.

Finca, Bongani 2007. Restitution Imperative in a Fragile Democracy. Paper delivered at the annual meeting of the Foundation for Church-led Restitution. Cape Town: Unpublished Document.

Hayner, Priscilla 2000. Same species, different animal: how South Africa compares to truth commissions worldwide. In Looking Back Reaching Forward. Reflections on the Truth and Reconciliation Commission of South Africa, (ed.) Villa-Vicencio, C; Verwoerd, W, 32-41. Cape Town: University of Cape Town Press/London: Zed Books Ltd.

Jandt, FE (ed.) 2004. Intercultural Communication. A Global Reader. London: Sage.

Louw, DJ 2006. Cura Vitae. Illness and the healing of life. Guidelines for pastoral care. Stellenbosch, Faculty of Theology: Unpublished document.

Maluleke, Tiniyiko 2008. Justice in post-apartheid South Africa: Towards a Theology of Restitution. Verbum Et Ecclesia 29 (3):681-696.

Mouton, Elna; Smit, Dirkie 2008. Shared Stories for the Future? Theological Reflections on Truth and Reconciliation in South Africa. Journal of Reformed Theology Vol. 2 (1):40-62.

Niebuhr, HR 1951. Christ and Culture. New York: Harper and Row.

Robertson, R 1992. Globalization, Social Theory and Global Culture. London: Sage.

Smit, Dirkie. 1984. Wat beteken status confessionis? In 'n Oomblik van waarheid. Opstelle rondom die NG Sendingkerk se afkondiging van 'n status confessionis en die opstel van 'n konsepbelydenis, (ed.) Cloete D; Smit D, 14-38. Kaapstad: Tafelberg Uitgewers. 
Swart, Ignatius 2008. Meeting the Challenge of Poverty and Exclusion: The Emerging Field of Developmental Research in South African Practical Theology. International Journal of Practical Theology. Volume 12, 2008. Issue 1:104-149.

Villa-Vicencio, Charles 1998. A Theology of Reconstruction. Nation-Building and Human Rights. Cape Town: David Philip Publishers.

Villa-Vicencio, C 1994. Theology and Culture in South Africa: Beyond multi-culturalism. In Theology Today 51/1 April 1994. 115-126.

Villa-Vicencio, Charles 2006. What a truth commission can and cannot achieve. In Truth and Reconciliation in South Africa: 10 Years On, (ed.) Villa-Vicencio, C; Du Toit, F, 2-8. Claremont: New Africa Books (Pty) Ltd.

Volf, Miroslav 1996. Exclusion \& Embrace: A Theological Exploration of Identity, Otherness, and Reconciliation. Nashville: Abingdon. 